\title{
(5)

\section{Mørket på jobben og mørket i meg}

ANMELDELSER

TROND HEIR

Professor i psykiatri, Universitetet i Oslo og Nasjonalt kunnskapssenter om vold og traumatisk stress

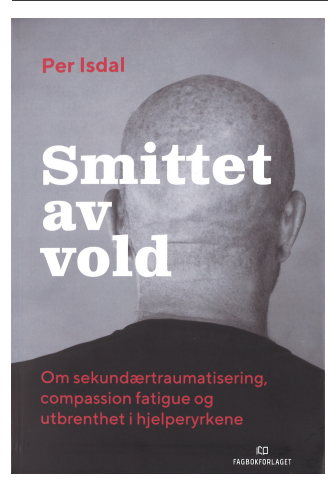

Per Isdal

Smittet av vold

Om sekundærtraumatisering, compassion fatigue og utbrenthet i hjelperyrkene. $306 \mathrm{~s}$, tab, ill. Bergen: Fagbokforlaget, 2017. Pris NOK 399

ISBN 978-82-450-2202-5

Per Isdal har arbeidet som psykolog i 30 år. Han ble høsten 2017 utnevnt til ridder av St. Olavs Orden for sitt pionerarbeid innen Stiftelsen Alternativ til Vold og sitt mangeårige engasjement for å hjelpe voldsutøvere.

I Smittet av vold fremhever han at det er et privilegium å få arbeide med mennesker, bety noe for dem og se dem komme ut av vanskene, men at dette også gjør oss sårbare. Møtet med andre menneskers lidelse, fortvilelse og sorg påvirker oss og over tid kan det forandre oss: "We cannot walk through water without getting wet».

Forfatteren forteller hvordan han etter mange år i sitt arbeid satte seg ned og fors $ø$ kte å skrive ned hvordan han hadde det med seg selv og livet. Han opplevde det som vondt å lese det han selv hadde skrevet. Han var blitt et menneske han helst ikke ville være: Sintere, mer kranglete, mindre omgjengelig og mindre sosial. Frustrasjonen han kjente tilla han enten andre; de var inkompetente eller idioter, eller egen utilstrekkelighet; han var ikke bra nok, flink nok, takknemlig nok. Det var først etter en grundig selvransakelse at han forsto at dette hadde noe med innholdet i jobben å gjøre: «Det mørket jeg møtte i jobben, ble til mørke i meg. Rundt meg så jeg andre hjelpere på mitt fagfelt som ble enda mer preget av arbeidet enn meg. Noen forsvant, og kom aldri tilbake».

Boken tar utgangspunkt i at «et arbeid i grusomhetens nærhet» medfører høy risiko for å bli 
preget og i ytterste forstand, syk av arbeidet. Denne erkjennelsen er en forutsetning for å kunne ta de nødvendige grep for å verne om hjelperens engasjement og helse.

Er det mulig å påvirke vår egen arbeidsdag og våre reaksjoner på andre menneskers lidelse? Ja, mener forfatteren. De mange råd og erfaringer som han deler, er verdt å ta med seg. Det dreier seg om individuelle og kollektive valg, politikk, betydningen av pauser og variasjon i arbeidet, utdanning, kompetanse og fagutveksling, farene ved opptrapping av lønnsomhetsmodeller og neglisjering av arbeidstakernes behov. Viktigheten av anerkjennelse, kollegastøtte, fellesskap og faglige møteplasser, autonomi og kontroll likeså. Vi som helsearbeidere må vise omsorg for oss selv og hverandre.

Aller best er boken der forfatteren deler egne og andres erfaringer fra ulike sider av hjelperrollen. Dette er engasjerende og godt skrevet - og gjenkjennbart. Med litt strammere rammer og et kortere format på deler av teorigrunnlaget ville teksten hevet seg ytterligere.

For dette er en viktig bok. Forfatteren skal ha stor takk for å ta oss med inn i de sårbares rekker. Han går foran i et tabubelagt område, og han gjør det med varme og empati. Kanskje har det vært slik at vi som hjelpere i liten grad har snakket om våre mest sårbare sider? Kanskje er vi lite forberedt på hva jobben gjør med oss?

Jeg benytter boken i undervisningen av medisinstudenter. Forteller dem at de kommer til å ta med seg jobben hjem, og at de kan komme til å bli både furet og værbitt av det yrkesvalget de har tatt. Men at det også finnes grep det kan være lurt å ta.

Boken anbefales til alle som har valgt å jobbe med mennesker i krise. Bevissthet om egne og andres reaksjoner samt mulige strategier og valg, kan gjøre yrkeslivet enda mer innholdsrikt både for oss selv og våre kolleger. Og det gjør oss uten tvil til bedre hjelpere.

Publisert: 19. februar 2018. Tidsskr Nor Legeforen. DOI: 10.4045/tidsskr.17.0980

(C) Tidsskrift for Den norske legeforening 2020. Lastet ned fra tidsskriftet.no 